Jasmina Ognjanović

University of Kragujevac,

Faculty of Hotel Management and Tourism,

Vrnjačka Banja
SCIENTIFIC REVIEW ARTICLE

doi:10.5937/ekonomika16031590

Received: Jun 6, 2016

Accepted: Jun 28, 2016

\title{
INTELLECTUAL CAPITAL: CHARACTERISTICS AND SIGNIFICANCE IN THE SERVICE SECTOR
}

\begin{abstract}
Intellectual capital is a main driver of creating value in the company by combining the use of human, structural and relational capital. It consists of knowledge and skills of employees, business culture, databases, company's reputation and relations with external partners. The aim of this paper is to point out the significance of intellectual capital and its impact on service creation and performance of service companies. Based on the applied inductive-deductive and qualitative method, we can come to the conclusion that human capital has a dominant role in service companies. The effect of human capital is conditioned by the existence of non-material infrastructure, i.e. structural capital. Creation of good competitive position of service companies can be achieved by developing relational capital. Therefore, service differentiation and good image of service companies in the environment can be achieved by owning and good management of intellectual capital, i.e. management of human, structural and relational capital.
\end{abstract}

Key words: intellectual capital, services, human capital, structural capital, relational capital

JEL classification: $\mathrm{M}_{21}, \mathrm{D}_{83}, \mathrm{~L}_{80}$

\section{ИНТЕЛЕКТУАЛНИ КАПИТАЛ: КАРАКТЕРИСТИКЕ И ЗНАЧАЈ У УСЛУЖНОМ СЕКТОРУ}

\begin{abstract}
Апстракт
Интелектуални капитал је главни покретач стварања вредности у предузећу комбинованом употребом ьудског, структурног и релационог капитала. Чини га знање, искуство и вештине запослених радника, пословна култура, базе података, репутација предузећа и односи са екстерним партнерима. Циљ рада је за истакне значај интелектуалног капитала и његов утииај на креирање услуга и перформансе услужних предузећа. На основу примењене индуктивно-дедуктивне и квалитативне методе закључује се да људски капитал има доминантну улогу у услужним предузећима. Деловаье људског капитала условљено је постојањем нематеријалне инфраструктуре односно структурног капитала. Креирање добре конкурентске позичије
\end{abstract}

${ }^{1}$ jasmina.lukic@kg.ac.rs 
услужних предузећа могуће је остварити развојем релационог капитала. Дакле, диферениираност услуга и добру слику услужних предузећа у окружењу могуће је постићи поседовањем и добрим управљањем интелектуалним капиталом односно управљањем људским, структурним и релационим капиталом.

Кључне речи: интелектуални капитал, услуге, људски капитал, структурни капитал, релациони капитал

\section{Introduction}

Creation of economic value in contemporary conditions is based on knowledge and other non-material resources. Drucker (1993) ponts out that knowledge is a main resource of modern economy and "knowledge workers" are the most important labour force. Basic component of intelectual capital (hereinafter IC) is knowledge. Intellectual capital is defined by Roos \& Roos (1997) as a set of invisible property of the company and the most important resources for acquiring competitive advantage of the company, whereas its is started from the fact that knowledge is crucial for acquisition of sustainable competitive advantage. In knowledge-based economy, it is important to stress the role of service sector since it has a share of more than 70\% in GDP in OECD countries and employs $65 \%$ of working population of these countries (OECD - Organisation for Economic Co-operation and Development, 2000). Main products of service sector are services that are largely results of the work with the help of knowledge and thus the role of intellectual capital, as value driver, is of crucial importance in this sector.

IC significance is different in manufacturing and service sector. The possibility of differentiating the services and the attempt of the company to distinguish itself from the group of many others that are similar, it is not possible to realize without the use of IC components - knowledge, skills and abilities of employees, adequate business culture, developed image and good cooperation with business partners and users. On the other hand, in manufacturing companies the incomes from service activities can have a high share in the structure of total income realized. For example, companies such as IBM, SKF and Xerox, create more than $30 \%$ of income on the basis of services provided whereas the share of service activities in the profit often exceeds 50\% (Gebauer et. al., 2010). Service companies become increasingly productive in industrial countries - to the extent that we could say we live in service-based ecomony (Kianto et. al., 2010). This statement is also confiremed by the data on the impact of this sector on creation of GDP, the number of workers employed in this sector and a part of personal income that population spends on services.

The significance of IC, as a significant company's strategic resource, is best illustrated by the theory based on resources. According to the authors Steenkamp \& Kashyap (2010), the IC significance comes from its role in development and creation of competitive advantage, provision of high profit potential for the future and high business performances. In addition to intellectual capital the second, most frequently used term in literature for the expression of non-material resources (knowledge, information, 
intellectual property, experience) that create value (Stewart, 1997) is intangible, nonmaterial, intellectual assets. (Lonnqvist, 2004).

The purpose of this paper is to point out IC role in contemporary business terms of the company, which are characterized by a high competition level and frequent changes of business conditions. In addition, we also point out the impact of this capital category to the creation of services and performances of service companies. The paper consists of three chapters where the first one describes IC, its components and characteristics, the second points out the characteristics of services, while the third one provides a review of previously published studies on the presence of IC and its components in service sector with a discussion on which IC components affect the service companies performances the most.

\section{Intellectual capital concept}

There are two ways to measure the value of the company, one is based on financial reports and the other on evaluation of the company by capital market. Deviation of market in relation to accounting value of the company was the main reason for studying the issues of intellectual capital. The authors Sveiby (1997) and Lev (2001) believe that the difference between market and accounting value of the company represents the value of intellectual capital. Having in mind the deviation between the values mentioned, some studies point out that more than $2 / 3$ of the value of company's property is IC (Van Buren, 1999) while others point out that $80 \%$ of market value makes this capital category (Tesng \& Goo, 2005). Many companies in USA in the period from 1981 to 1993 had the value that was 2-9 times more in capital market in relation to their accounting value (Edvinsson, 1997), which points to the high impact of IC on company's market values.

Intellectual capital, as a crucial strategic resource of the company is actually based on knowledge. The knowledge is a main component of human capital, which is a result of learning process. In addition to human, intellectual capital also consists of structural and relational capital that affect value creation. Edvinsson (1997) observes IC as the most important resource in value creation process in the company. What follows is the defining of the intellectual capital by different authors, in chronological order.

Among the first ones, the term intellectual capital is explained by Itami (1991) as a set of a big number of elements, such as technology, client loyalty, company's image, corporative culture and skills management. Brooking (1996) sees IC as a combination of four categories: market property, intellectual property, human resources and infrastructure. Edvinsson \& Malone (1997) defines IC as a knowledge that can be transformed into value while Stewart (1997) by IC implies packed useful knowledge, i.e. company's intellectual material - knowledge, information, intellectual property and experience - which can be used for wealth creation. The primary definition of IC within Swedish insurance company Skandia referred to the possession of knowledge, experience applied, organization technology, consumer relations and professional skills that provide competitive advange for this company in the market. (Edvinsson, 1997).

Lynn (1998) by IC implies intellectual material that is used for creation of value added. Nahapiet \& Ghoshal (1998) use the term IC in order to mark a significant resource and ability to take over the actions based on knowledge and skills. Lev (2001) observes 
how IC as non-material resources are generated by innovations, unique organizational design and experience of the employees. Intellectual capital is a combination of human, structural and relational resources of the company (MERITUM, 2002). According to Lonnqvist (2004), IC includes non-physical resources that refer to skills of employees, organizational resources, manner of performing activities and relations with company's stakeholders. Intellectual capital is a competition leverage for small innovation companies, i.e. IC is main internal determinant of the competitiveness of small and medium companies (Tovstiga \& Tulugurova, 2007). In Table 1, you can see the review of IC characteristics.

Table 1: Review of intellectual capital characteristics

\begin{tabular}{|c|c|}
\hline Autor(s) & IC characteristics \\
\hline Carnall (1999) & $\begin{array}{l}\text { - It is difficult to accumulate non-material resources } \\
\text { - Simultaneous multiple use } \\
\text { - Simultaneously being both inputs and outputs of business }\end{array}$ \\
\hline $\begin{array}{l}\text { Riahi-Belkaoui (2003); } \\
\text { Grosh \& Wu (2007) }\end{array}$ & $\begin{array}{l}\text { - Rarity } \\
\text { - value } \\
\text { - impossible to imitate } \\
\text { - } \text { non-existence of substitutes }\end{array}$ \\
\hline Gallego \& Rodríguez (2005) & $\begin{array}{l}\text { - intangible nature } \\
\text { - results of economic transactions } \\
\text { - ability for creating future income } \\
\text { - resources used in the long run }\end{array}$ \\
\hline Tesng \& Goo (2005) & $\begin{array}{l}\text { - intangibility } \\
\text { - effect of time delay (benefits from R\&D function last 5-9 } \\
\text { years) } \\
\text { - not present the zero sum effect (gain on one side equals the } \\
\text { loss on the other) } \\
\text { - multiplication rule } \\
\text { - yield increase right (factors value increases with the use) }\end{array}$ \\
\hline
\end{tabular}

Based on different definitions of IC term, the conclusion can be reduced to the following: IC is a main driver of value creation in the company by combing human, structural and relational factor. Intelectual capital consists of knowledge, experience and skills of the workers employed, business culture, databases, company's reputation and relations with business partners. Therefore, we can list the most important characteristics of IC: intangibility, impossible to imitate; bigger intensity of using intellectual resources increases their value and craetes future long term benefits.

Over the time, significance of intellectual capital was growing in modern economy, different authors have attempted to define its components in the most comprehensive way possible. As it was mentioned before, it is one "intangible property"whose value is difficult to assess. For proper evaluation of IC it is necessary to, first of all, understand its components and their impact on value creation process.

Brooking (1996) points out market property, intellectual property, human resources and infrastructure as components of IC. Edvinsson \& Malone (1997) and i Organisation 
for Economic Co-operation and Development - OECD, 1999 divide IC into human and structural. Lev (2001) classifies IC into innovation, human and organization resources while Sveiby (1997) and O'Donnell \& O'Regan (2000) divide IC into competence of the employees, internal and external structure.

For the purposes of this paper, the classification of IC into human, structural (organization) and relational (external) capital (Roos \& Roos, 1997, Bontis, 1998, Guidelines for Managing and Reporting on Intangibles - MERITUM Guidelines, 2002).

Human capital, in MERITUM Guidelines (2002), is defined as knowledge that employees bring along when they leave the company and it includes knowledge, experience, creativity, skills of employees. Mihailović, et. al. (2015) point out that main driver of development and business success of the company is precisely the continuous learning and improvement of skills and abilities of management and employees. Structural capital or, as it is often called, organizational or internal capital is defined by Bontis (2001) as a combination of databases, software, hardware, organizational structure, patents, trademarks and all other organizational capacities that support the productivity of employees. Relational capital includes all resources related to business interactions of company with external environment - with buyers, suppliers or research and development partners (Guidelines for Managing and Reporting on Intangibles MERITUM, 2002).

\section{Service characteristics}

According to OECD (2000) data, service sector is becoming increasingly important in information society: share of manufacturing activities is gradually reduced to level below $20 \%$ while the share of service sector in GDP of OECD countries is more than $70 \%$; employees in this sector make about $65 \%$ of total number of employees (OECD, 2000). Main task of service sector development is the creation of the assumptions of creating such services that the consumer will observe as something that provides him an attractive value added.

Selection of services is based on expectations and desires. Desires refer to the manner in which the consumer tries to satisfy his needs. The expectations are related to the aim of the user and based on user needs and desires whose realization is conditioned largely by the elments of relation capital: reputation of the company in the market, marketing, earlier experience of the user with service company, etc. (Edvardsson \& Olsson, 1996). When the expectations and desires of users are satisfied, the value is created. The value can be measured by putting the service quality level and the costs of their provision into relation (Sandstrom et al., 2008).

Numerous authors mention the intangibility as an important characteristics of services (Parasuraman et. al., 1985, Moeller, 2010 and Rodie \& Martin 2001). The decision on selection of services depends on how the potential user experiences the intangibity feature. However, majority of services cannot be expressed in numbers, measured, tested, which makes the choice more difficult. Due to intangibility, managers cannot easily understand how the consumer sees their services and evaluate their quality, which can create a problem in service creation (Parasuraman et. al., 1985). Intangibility gives creators space to create a service that can be different from the others. In addition, 
intangibility makes service imitation more difficult for the competitors. Creation of a unique, differentiated, intangible service depends on intellectual capital that service company owns, i.e. knowledge, skills and abilities of employees to create innovation services with the support of appropriate infrastructure such as database, business culture, hardware, software, i.e. structural capital. Maintenance of good business relations with familiar customers, with whom a company has a long, successful cooperation, as well as image of the company itself is a verified recipe for high business performances.

Intangibility of services affects the height of company's income through the possibility of differentiation and inability of imitation by the competition. In the same way, intangible nature of IC plays an important part in role creation process of which successful usage also depends the quality of services as well as the height of income in the company. Therefore, IC affects high business income of service companies through the impact on production of differentiated services that will entirely satisfy the expectations and desires of users. Once more, we must stress that intangible resources are main source of competitive advantage in knowledge-based economy (Zigan \& Zeglat, 2010). Unique and quality services, in contemporary conditions, can be created only with the usage of human, structural and relational capital.

\section{Intellectual capital in service sector}

Main role in service sector belongs to the user, because without him there is no income. It is required that there is a harmony, compatibility between service offer and the needs of service users. Needs and satisfaction of needs are the basis of service creation process. Requests of service users and manner of their satisfaction are different among individual users. The essence is to create a service that meets the expectations of users and creates a value added for him. In order to achieve that, it would be good to "include" the user in the very process of developing new types of services, which acquires a high level of closeness between participants in supply and demand of services. Williams et. al. (2010) and Anantadjaya et. al. (2015) point out that closeness between producers and users of services can be achieved if the producers track the behaviour, attitudes and needs of users and understand what are the "vulnerable" spots in their expectations which creates a high level of loyalty and confidence of users who, in the economy based on knowledge, become very important.

In this paper, service sector is seen as a sector consisting of services of communication, finances, trade, education, health protection, real estate rent, food and accommodation and public administration services (OECD, 2000). The study carried out by Bontis et. al. (2000), includes government, financial services, entertainment, hospitality and tourism, private education, computer and professional services in service sector, while chemical, electronic companies, manufacturing and construction companies are included in non-service sector. Lim \& Dallimore (2004) in their study, by service companies include banking companies, companies from telecommunication, entertainment and tourism field, transport and financial companies.

It is already said that IC includes human, structural and relational capital. In this order we will present works that have so far analized the role of all the components in service sector and their basic conclusions. 
Human capital is a very important component of IC having in mind that it largely affects the work productivity. Some characteristics of employees, such as experience, abilities, affect the perceived value of service users. Studies show that "loyalty of the customers" can be predicted by measuring "loyalty of the employees" (Bontis et. al. 2000).

Namasivayam \& Denizci (2006) have analized the impact of human capital in service companies. Authors believe that human features, such as creativity and emotional intelligence of the employees must be adequately evaluated since they affect the perceived value of the consumer. Based on their work, we come to the conclusion that business processes of service companies are closely related to human capital, where the authors see the value created for the users in the following manner (Namasivayam \& Denizci, 2006):

\section{Human capital * structural capital $=$ value for consumers}

Human capital, along with structural capital, is especially important in the relations between service user and service provider. For service users, it is important that provider has the knowledge in order for their desires to turn into a specific role. In addition, it is important to recognize the form and nature of knowledge and contribution of each employee.

Significance of human capital, as IC component in service companies was also pointed out by Edvardsson \& Olsson, (1996). This capital is seen as a crucial resource of the company. Perception of consumers on service quality largely depends on how the employees see their desires and needs. Due to the employees, service becomes "visible" so in that way, knowledge, experience and motivation of employees have a significant contribution to the achievement of high performances of service companies. In addition to the impact on service quality, employees are important factor in the field of costs as well - earnings of employees in service sector are higher on the average in relation to manufacturing companies.

The IC significance in service companies was also studied by Kianto et al. (2010) where they reach the conclusion that in these companies there is increasingly more expressed demand for multiple and complex knowledge of employees in relation to manufacturing companies so the role of people (human capital) is much more important in service sector since the quality of service provided largely depends on them. They point out that IC is the crucial driver of value, regardless of the type of activity that the company deals with. Lim Dallimore, (2004) in this study, based on 36 service companies in Australia, point out both human and relational capital as the most important components of IC. These categories of capital provide significant benefits for the existing and potential investors, as well as higher service quality. Navaratnam \& Harris, (1994) define five management principles that can strengthen human capital as main creator of value. Those principles are: respecting people, management based on facts; satisfaction of consumers and teamwork.

Martelo-Landroguez \& Martin-Ruiz (2016) were engaged in examining the impact of knowledge to creating the value for service user. Study was carried out on an example of banking sector of Spain and starting assumption that service companies that use their knowledge more efficiently create more benefits for their clients was confirmed. 
A small number of authors have dealt with examining the role of structural capital in service companies. Kianto et al. (2010) start from assumption that structural capital is somehow more important for manufacturing companies in relation to service. However, IT application in service sector changes the role of structural capital in service companies. Components of structural capital, such as information and communication systems, are extremely important not only because of optimal process of work but also because of the satisfaction between the users of these systems, i.e. employees (Zigan \& Zeglat, 2010).

Castro et. al. (2004) analyze the role of company's reputation in development of relational capital and point out that relations of the enterprise make its most valuable assets. Kianto et al. (2010) believe that relational capital is more important for service than manufacturing companies having in mind it is required to make a harmony between the supply and demand of customers. A close relationship between manufacturers and users of services imposes a need for establishing a good relationship and mutual understanding between these two participants. Having in mind that a small number of authors deals with analyzing relational capital in service companies, in this paper we start from a brand, image of the company as an important component of relational capital. Brady et. al. (2005) in their reasearch work point out the significance of branding the services in relation to physical goods and point to a direct relation between the service intangibility level and significance of branding. In addition, Krishnan \& Hartline (2001) in their paprt, point out the significance of the brand in evaluation of services quality. For the authors, Zigan \& Zeglat (2010) satisfaction and loyalty of service users, relations with suppliers and reputation of the company represent the most important components of relation capital in case of service, hospitality companies.

Intangibility makes service selection harder from the part of users and thus the brand can appear as a service differentiation source. Strong brand has a positive impact, directly or indirectly, to the perceived service quality in case of consumers. Onkvisit \& Shaw (1989) point out of the significance of the brand in service selection by the part of consumers and they observe services as goods. They mention Holiday Inn as the first company that branded its services in hospitality industry. Using brand name ensured unique, standardized services for the tourists everywhere in the world, where this company has transformed accomodation services into goods.

Inspired by characteristics of hospitality industry, the authors Fitzgerald et. al. (1991) have defined a system for measurement of business performances in service sector. System is based on connecting financial and non-financial measures in order to control and develop performances of service companies. Dimenions and measures in this model reflect the characteristics of service sector. The system connects financial and non-financial measures and includes six categories summed up in two groups: the first is results dimension, which includes competitiveness and financial results and the second one is determinist dimension, which contains factors that affect all the performances service quality, flexibility, resource usage and innovations. Model measures efficiency and productivity of resources (Zigan Zeglat, 2010).

In Table 2, a review of scientific papers that have dealt with examining IC impact on business of service company is presented. 


\section{Table 2: Review of previous studies of IC impact on business of service companies}

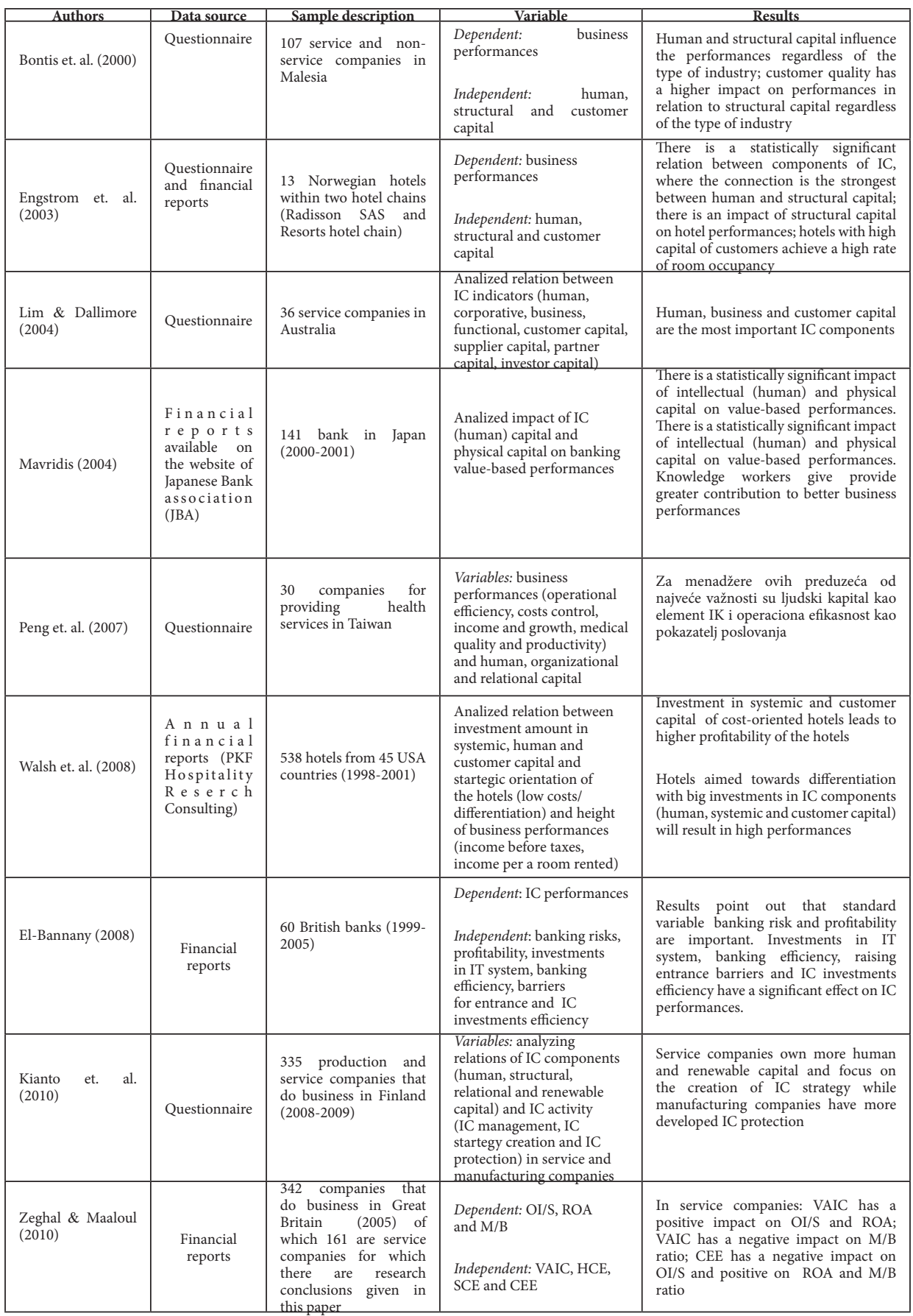




\begin{tabular}{|c|c|c|c|c|}
\hline $\begin{array}{l}\text { Bontis et. al. } \\
(2013)\end{array}$ & $\begin{array}{l}\text { Financial } \\
\text { reports }\end{array}$ & $\begin{array}{l}\text { Banks that do business } \\
\text { in Serbia }(2008-2011)\end{array}$ & $\begin{array}{l}\text { Dependent: profitability, } \\
\text { total assets, ROA, ROE, } \\
\text { productivity of employees } \\
\text { Independent: HCE, SCE; } \\
\text { CEE }\end{array}$ & $\begin{array}{l}\text { Results show that human capital } \\
\text { has an impact on productivity of } \\
\text { employees, structural capital on total } \\
\text { assets and ROE and physical capital on } \\
\text { profitability and ROE }\end{array}$ \\
\hline Joshi et. al. (2013) & $\begin{array}{l}\text { Financial } \\
\text { reports }\end{array}$ & $\begin{array}{l}40 \text { financial companies } \\
\text { in Australia } \\
\text { ( c o m m e r c i a l, } \\
\text { investment banks, } \\
\text { insurance companies) }\end{array}$ & $\begin{array}{l}\text { Dependent: ROA } \\
\text { Independent: VAIC, CEE, } \\
\text { HCE, SCE }\end{array}$ & $\begin{array}{l}\text { Relation between VAIC, HCE and SCE } \\
\text { and ROA is not statistically significant. } \\
\text { Relation between CEE and ROA is not } \\
\text { statistically significant }\end{array}$ \\
\hline $\begin{array}{l}\text { Bornemann \& } \\
\text { Wi ed e n h of e r } \\
(2014)\end{array}$ & $\begin{array}{l}12 \text { case studies } \\
\text { performed on } \\
\text { the example } \\
\text { of Austrian } \\
\text { educational } \\
\text { institutions }\end{array}$ & $\begin{array}{l}\text { Austrian educational } \\
\text { institutions } \\
2013)\end{array}$ & $\begin{array}{l}\text { Application of IC concept } \\
\text { to non-material resources } \\
\text { as crucial for the quality of } \\
\text { education process. The aim } \\
\text { is to identify the cause of } \\
\text { interdependence between } \\
\text { IC ininitiator and generic } \\
\text { processes of educational } \\
\text { institutions }\end{array}$ & $\begin{array}{l}\text { Pointing out the priority of limited } \\
\text { resources and systematic monitoring } \\
\text { in IC in public and private educational } \\
\text { institutions contributes to economic } \\
\text { improvement and better acquisition of } \\
\text { startegic goals }\end{array}$ \\
\hline
\end{tabular}

Legend: OI/S (Operating Income per Sales); HCE (Human Capital Efficiency); SCE (Structural Capital Efficiency); CEE (Capital Employed Efficiency); ROA (Return on Assets); ROE (Return on Equity); GR (Growth Revenue); EP (Employee Productivity); M/B (Market to Book Ratio); VAIC (Value Added Intelectual Coefficient)

Based on papers presented in Table 2, authors of the four papers et. al. (2000); Lim \& Dallimore (2004); Zeghal \& Maloul (2010) and Kianto et al. (2010) have studied IC impact on performances of service companies. Some authors have examined the IC impact on companies that deal with one of service activities: hotels - (Engstrom et. al. 2003; Walsh et. al. 2008), financial institutions (Mavridis 2004; El-Bannany 2008; Bontis et. al. 2013; Joshi et. al. 2013); health institutions (Peng et. al. 2007); education institutions (Bornemann \& Wiedenhofer 2014). By summarizing the studies presented, the conclusion could be reduced to the fact that IC components (human, structural and relational capital) have an impact on business performances of the observed, service companies and that there is a significant connection between coefficients of IC components Sumiranjem prikazanih istraživanja, zaključak bi se mogao svesti na to da komponente IK (HCE; SCE and VAIC) and financial indicator (ROA) in the paper of the author Joshi et. al. (2013).

The growth of service companies is based on the use of intellectual capital. Efficient use of IC contributes the creation of differentiated and quality services and offers company a possibility to achieve better competing position. Effects of IC activities are expressed through the usage of its components: human, structural and relational capital. Human capital has a dominant role in service companies and includes knowledge, abilities and skills of employees to create quality services, different in relation to competition. Structural capital (databases, softwares, business culture) represent a tool which enables the employess to use knowledge and skills while development of relational capital affects good competing position and image that a company has in its environment. Therefore, differentiation of services and better competing position of service companies can be achieved by owning and good management of intellectual capital, i.e. management of human, structural and relational capital. 


\section{Conclusion}

Value of the company is not based only on physical and financial, but also on intelectual property. Intellectual capital is something unique that a company owns (Bontis et. al. 1999) and makes up $80 \%$ of its market value (Cheng et. al. 2010). IC is built within “company's walls" (Komnenic \& Pokrajcic, 2012) and therefore, it is hard to distinguish this type of capital from total company's assets. Authors Kim \& Dennis (2014) believe that growth in knowledgebased economy is a main reason of deviation of market value of the company in relation to the accounting value. This difference simultaneously points to the positive impact of IC on business of the company and there are numerous studies regarding this subject.

IC is an important factor of creating value in the companies, whether they are manufacturing, trade or service. It consists of human capital (knowledge, experience and skills of the employees), structural capital (business culture, databases) and relational capital (reputation of the company and relations with external partners). Investing in IC is a secure path to creation of competitive advantage and high business performances of the company.

High value of IC affects the growth of the value of service companies. Possession of IC in service companies and its adequate usage offers the possibility to produce differentiated, quality services that can be copied easily. By creating these services, the growth of profit is provided which leads to the growth of the value of the company.

\section{References}

Anantadjaya, S., Nawangwulan, I., Pramesty, I.A. \& Gunawan, G.A. (2015). Measuring customers' intimacy: evidence from indonesian service-based companies. Ekonomika, Vol. 61(2), 11-28.

Bontis, N. (1998). Intellectual capital: an exploratory study that develops measures and models. Management Decision, 36(2), 63 - 76.

Bontis, N. (2001). Assessing knowledge assets: a review of the models used to measure intellectual capital. International Journal of Management Reviews,3(1), 41-60.

Bontis, N., Dragonetti, N., Jacobsen, K. \& Roos, G. (1999). The knowledge toolbox: A review of the tools available to measure and manage intangible resources. Eropean Management Journal, 17(4), 391-402.

Bontis, N., Janošević, S. \& Dženopoljac, V. (2013). Intellectual capital and the corporate performance of Serbian banks. Actual problems of Economics, 4, $287-$ 299.

Bontis, N., Keow, W.C. \& Richardson, S. (2000). Intellectual capital and business peformance in Malaysian industries. Journal of Intellectual Capital, 1(1), 85 100.

Bornemann, M. \& Wiedenhofer, R. (2014). Intellectual capital in education: a value chain perspective. Journal of Intellectual Capital, 15(3), $451-470$.

Brady, M.K., Bourdeau, B.L. \& Heskel, J. (2005). The importance of brand cues in intangible service industries: an application to investment services. Journal of Services Marketing, 19(6), $401-410$. 
Brooking, A. (1996) Intellectual Capital: Core Asset for the Third Millennium Enterprise, London: Thompson International Business Press

Carnall, C. (1999) Managing change in organizations, $3^{\text {ed }}$ ed., Edinburgh: Pearson Education Limited, England.

Castro, G.M., Saez, P.L. i López, J.E.N. (2004). The role of corporate reputation in developing relational capital. Journal of Intellectual Capital, 5(4), 575 - 585.

Cheng, M.Y., Lin, J., Hsiao, T. \& Lin, T.W. (2010). Invested resource, competitive intellectual capital, and corporate performance. Journal of Intellectual Capital, 11(4), $433-450$.

Drucker, P.P. (1993). Managing in Turbulent Times,New York: Harper Business,

Edvardsson, B. \& Olsson, J. (1996). Key Concepts for New Service Development. Service Industries Journal. Apr. 96. 16(2), 140-164.

Edvinsson, L. \& Malone, M. (1997). Intellectual Capital: Realizing your Company's True Value by Finding its Hidden Brainpower, New York:Harper Collins.

Edvinsson, L. (1997). Develoing intellectual capital at Skandia. Long Range Planning. 30(3), 366-73.

El-Bannany, M. (2008). A study of determinants of intellectual capital performance in banks: the UK case. Journal of Intellectual Capital, 9(3), 487 - 498.

Engstrom, T., Westnes, P. \& Westnes, S.F. (2003). Evaluating intellectual capital in the hotel industry. Journal of Intellectual Capital, 4(3), 287 - 303.

Fitzgerald, L., Johnston, R., Brignall, S., Silvestro, R. \& Voss, C. (1991). Performance Measurement in Service Business, CIMA, UK.

Gallego, I. \& Rodríguez, L. (2005). Situation of intangible assets in Spanish firms: an empirical analysis. Journal of Intellectual Capital, 6(1), 105 - 126.

Gebauer, H., Edvardsson, B. \& Bjurko, M. (2010). The impact of service orientation in corporate culture on business performance in manufacturing companies. Journal of Service Management, 21(2), 237 - 259.

Grosh, D. \& Wu A. (2007). Intellectual capital and capital markets: additional evidence. Journal of Intellectual Capital, 8(2), 216 - 235.

Ilias, S. \& Panagiotis, T. (2010). Investigating the impact of service quality and customer satisfaction on customer loyalty in mobile telephony in Greece. The TQM Journal, 22(3), 330-343.

Itami, H. (1991) Mobilizing Invisible Assets. Cambridge: Harvard University Press.

Joshi, M. et. al. (2013). Intellectual capital and financial performance: an evaluation of the Australian financial sector. Journal of Intellectual Capital, 14(2), 264 - 285.

Kianto, A., Hurmelinna-Laukkanen, P. Ritala, P. (2010). Intellectual capital in service and product-oriented companies. Journal of Intellectual Capital, 11(3), $305-325$.

Kim, S. H. \& Dennis, T. (2014). Intellectual capital vs the book-value of assets. Journal of Intellectual Capital, 15(1), $65-82$.

Komnenic, B. \& Pokrajcic, D. (2012). Intellectual capital and corprate performance of MNCs in Serbia. Journal of Intellectual Capital, 13(1), 106-119. 
Krishnan, B.C. \& Hartline, M.D. (2001). Brand equity: is it more important in services?. Journal of Services Marketing, 15(5), 328 - 342.

Lev, B. (2001). Intangibles: Management, Measurement and Reporting. Washington:Brookings institution Press, DC.

Lim, L. \& Dallimore, P. (2004). Intellectual capital: management attitudes in service industries. Journal of Intellectual Capital, 5(1), 181 - 194.

Lonnqvist, A. (2004). Measurement of intangible success factors: case studies on the design, implementation and use of measures. Doktorska disertacija, Publication 475, Tampere University of Technology, Tampere.

Lynn, B. (1998). Intellectual capital. CMA Magazine, 72(1), 10. 6p. 1 Color Photograph

Martelo-Landroguez, S. i Martin-Ruiz , D. (2016). Managing knowledge to create customer service value. Journal of Service Theory and Practice, 26( 4).

Mathieu, V. (2001). Service strategies within the manufacturing sector: benefits, costs and partnership. International Journal of Service Industry Management, 12(5), $451-475$.

Mavridis, D. (2004). The intellectual capital performance of the Japanese banking sector. Journal of Intellectual Capital, 5(1), $92-115$.

MERITUM (2002). Guidelines for Managing and Reporting on Intangibles, Madrid, Spain: Measuring Intangibles to Understand and Improve Innovation Management. Dostupno na: http://www.pnbukh.com/files/pdf_filer/MERITUM_ Guidelines.pdf

Mihailović, B., Cvijanović, D. \& Simonović, Z. (2015). Role of business ethics in management of human resources. Ekonomika, Vol. 61(1), 85-96.

Moeller, S. (2010) "Characteristics of services - a new approach uncovers their value", Journal of Services Marketing, 24(5): 359 - 368.

Nahapiet, J. Ghoshal, S. (1998). Social capital, intellectual capital and the organizational advantage. Academy of Management Review, 23(2), 242-266.

Namasivayam, K. \& Denizci, B. (2006). Human capital in service organizations: identifying value drivers. Journal of Intellectual Capital, 7(3), 381 - 393.

Navaratnam, K.K. \& Harris, B. (1994). Customer Service in an Australian Quality Award Winning Public Sector Service Industry. International Journal of Public Sector Management, 7(2), $42-49$.

O’Donnell, D. \& O'Regan, P. (2000). The structural dimensions of intellectual capital: emerging challenges for management and accounting. Southern African Business Review: Special Issue on Information Technology, 4(2), 14-20.

Onkvisit, S. \& Shaw, J.J. (1989). Service marketing: image, branding, and competition. Business Horizons, 32(January-February), 13-18.

Organisation for Economic Co-operation and Development - OECD (2000). The Service Economy.Business and Industry Policy Forum Series. Dostupno na: http://www.oecd.org/sti/ind/2090561.pdf

Parasuraman, A., Zeithaml, V. i Berry, L. (1985). A conceptual model of service quality and its implications for future research. Journal of Marketing, 49(Fall), 41-50. 
Peng, T.A., Pike, S. \& Roos, G. (2007). Intellectual capital and performance indicators: Taiwanese healthcare sector. Journal of Intellectual Capital, 8(3), 538 - 556.

Riahi-Belkaoui, A. (2003). Intellectual capital and firm performance of US multinational firms. Journal of Intellectual Capital, 4(2), 215 - 226.

Rodie, A.R. i Martin, C.L. (2001). Competing in the service sector - The entrepreneurial challenge. International Journal of Entrepreneurial Behavior \& Research, 7(1), $5-21$.

Roos, G. \& Roos, J. (1997). Measuring your company’s intellectual performance. Long Range Planning, 30(3), 325, 413-426.

Sandstrom, S., Edvardsson, B. Kristensson, P. i Magnusson, P. (2008).Value in use through service experience. Managing Service Quality: An International Journal, $18(2), 112-126$.

Steenkamp, N. \& Kashyap, V. (2010). Importance and contribution of intangible assets: SME managers perceptions. Journal of Intellectual Capital, 11(3), 368 -390 .

Stewart, T.A. (1997). Intellectual Capital: The New Wealth of Organisation, London:Nicholas Brealey

Sveiby, K.E. (1997). The New Organizational Wealth: Managing and Measuring Knowledge-based Assets. San Francisco: Berrett-Koehler.

Tesng, C.Y. Goo, Y.J. (2005). Intellectual capital and corporate value in an emerging economy: empirical study of Taiwanese manufacturers. R\&D Management, $35(2), 187-201$.

Tovstiga, G. \& Tulugurova, E. (2007). Intellectual capital practices and performance in Russian enterprises. Journal of Intellectual Capital, 8(4), 695 - 707.

Van Buren, M.E. (1999). Making knowledge counts: knowledge management systems and the human element.

Walsh, K., Enz, C. \& Canina, L. (2008). The impact of strategic orientation on intellectual capital investments in customer service firms. Journal of Service Research, 10(4), 300-17.

Williams, K. C., Hernandez, E. H., Petrosky, A. R., \& Page, R. A. (2010). Fine-Tuning Useful E-Commerce Practices. Journal of Technology Research.

Zeghal, D. \& Maaloul, A. (2010). Analysing value added as an indicator of intellectual capital and its consequences on company performance. Journal of Intellectual Capital, 11(1), $39-60$.

Zigan, K. \& Zeglat, D. (2010). Intangible resources in performance measurement systems of the hotel industry. Facilities, 28(13/14), $597-610$. 